\title{
Dispute Settlement in EU Free Trade Agreements with Arab Countries
}

\section{Bashar H. Malkawi}

\section{Introduction}

International trade constitutes a vital lynchpin of the global governance architecture with staggering trillions of U.S. dollars worth of annual trade. ${ }^{1}$ The global trade order consists of trade policies and systems - in particular FTAs - which have played an increasingly crucial role in the infrastructure of global governance and substantially impacting international economic development and strategic affairs. The trade infrastructure is inextricably linked with global financial institutions and power politics and intertwined with military and political alliances. ${ }^{2}$

In recent decades, global economic governance has promoted free trade and trade liberalization through regional trade agreements (RTAs) to improve economic welfare of which FTAs form the overwhelming majority of agreements. ${ }^{3}$ FTAs have been perceived as stoking global economic growth as well fostering vigorous economic benefits to trade partners and gained in popularity following the failures to implement World Trade

\footnotetext{
${ }^{1}$ In 2016, there was U.S. \$20 trillion worth of global trade in goods and services. See WTO, World Trade Statistical Review, available at <https:/www.wto.org/english/res_e/statis_e/wts2016_e/wts2016_e.pdf>, 18 (2016).

${ }^{2}$ Helen Milner, The Political Economy of International Trade, 2 Annu. Rev. Polit. Sci. 105, 118 (1999). Power politics matters in the global trade paradigm as powerful states may violate their trade commitments toward weaker trading partners, knowing that weaker states are unlikely to carry out retaliation against them. See Anu Bradford \& Eric A. Posner, Universal Exceptionalism in International Law, 52 Harvard International Law Journal 3, 11 (2011).

${ }^{3}$ See Chankwon Bae and Yong Joon Jang, The Impact of Free Trade Agreements on Foreign Direct Investment: The Case of Korea, 17 Journal of East Asian Economic Integration 417, 423(2013) (In particular, free trade agreements (FTAs) [], account for $90 \%$ of the total number of RTAs.) See also Bashar H. Malkawi, Rules of origin under US Trade Agreements with Arab countries: Are they Helping and Hindering Free Trade? 10 Journal of International Trade Law and Policy 29, 33 (rules of origin in some FTAs are complex and protectionist and may act as barriers to trade).
} 
Organization modifications post-Doha leading to proliferation of FTAs in the early 2000 s. $^{4}$

FTAs are contractual obligations between the parties to reduce or eliminate tariffs and other trade restrictions on imports and a wide array of economic sectors. ${ }^{5}$ The goals of FTAs are to promote cross-border trade and investment and provide a stimulus to the economy of the trade partners. FTAs arise from perceptions between trading partners that an FTA would benefit the partners by - at a minimum - reducing or eliminating trade barriers and tariffs and establishing rules with respect to what constitutes a product manufactured within the FTA i.e. rules of origin. ${ }^{6}$

There are many benefits ascribed to FTAs such as vigorous global trade and encouraging efficient allocation of resources, enhanced consumer options and overall lower economic costs. FTAs are widely acknowledged as promoting trade liberalization and access to markets creating a more dynamic economic environment. Trade is considered as an important catalyst of economic growth. Trade promotes more efficient and effective production of goods and services to the countries which have comparative

\footnotetext{
${ }^{4}$ See Masahiro Kawai and Ganeshan Wignaraja, Free Trade Agreements in East Asia: A Way toward Trade Liberalization? Available at $<$ https://www.adb.org/sites/default/files/publication/28490/adb-briefs2010-1-free-trade-agreements.pdf $>$ (2010) (The inability to conclude the World Trade Organization (WTO) Doha Development Round has spawned a proliferation of bilateral and plurilateral free trade agreements (FTAs) across the globe) See also Hitoshi Sato, and Ikumo Isono, Impacts of Free Trade Agreements on Business Activity in Asia: The Case of Japan Daisuke Hirastuka, available at $<$ https://www.adb.org/sites/default/files/publication/155998/adbi-wp143.pdf> p.2 (2009) page 2 (Efforts to liberalize global trade through the World Trade Organization (WTO) have made limited progress since the Doha round of negotiations was launched in 2001.... [The] disappointing consequences have forced the WTO member countries (US and EU in particular) to choose alternative paths such as FTAs to promote trade. The trend toward FTAs has generated a domino effect in which one FTA triggers the creation of others). See also Julien Chaisse and Mitsuo Matsushita, Maintaining the WTO's Supremacy in the International Trade Order: A Proposal to Refine and Revise the Role of the Trade Policy Review Mechanism, 16 Journal of International Economic Law 9, 18-20 (2013).

${ }^{5}$ See, e.g., Korea FTA chs. 3, 7, 11, 12, and 18, 46 I.L.M. 642 (2007).

${ }^{6}$ William H. Cooper, Free Trade Agreements: Impact on U.S. Trade and Implications for U.S. Trade Policy, p.2-4 (2014), available at $<$ https://fas.org/sgp/crs/row/RL31356.pdf > (Rules of origin prevent products from nonmembers entering an FTA market over the lowest tariff wall. Most FTAs also include procedures on the settlement of disputes arising among members and rules on the implementation of border controls, such as product safety certification and sanitary and phytosanitary requirements)
} 
advantage in producing them. ${ }^{7}$ The economic benefits of FTAs are so well-recognized that even on an individual business person level, let alone company level, there is a strong interest in pursuing FTAs. ${ }^{8}$ FTAs could also provide other less tangible benefits. The signing of FTAs not only signifies economic cooperation between nations, but also cooperation on the political and institutional fronts. ${ }^{9}$

FTAs and free trade are not without criticism. Although the essential construct of FTAs is tariff and barrier elimination, more recent FTAs are more ambitious and include chapters on investment rules and intellectual property rights in a way that go beyond what is covered by the GATT/WTO ${ }^{10}$ In addition, opposing economists claim that FTAs are inferior to the WTO order and they undermine the multilateral trading system. ${ }^{11}$

\section{The Importance of Dispute Settlement Provisions in FTAs}

It is assumed that the parties to the FTA will carry out their commitments in good faith. Persons and companies would risk capital and may suffer potential loss; therefore FTAs require a strong legal foundation incentivizing stability, transparency and compliance with obligations. Legal guarantees and the knowledge disputes will be fairly

\footnotetext{
${ }^{7}$ See Najabat Ali, Li Xialing, Foreign Direct Investment, International Trade and Economic Growth in Pakistan's Economic Perspective, 7.5 American Journal of Economics 211-215 (2017).

${ }^{8}$ See Jeffrey J. Schott, Free Trade Agreements: The Cost of U.S. Nonparticipation, Testimony before the Subcommittee on Trade. House Ways and Means Committee (March 29, 2001) (arguing that to counter the fact that FTAs are rapidly forming in which the United States is not a participant, the US must vigorously negotiate FTAs or risk harming US interests).

${ }^{9}$ See S. M. Thangavelu and C. Findlay, The Impact of Free Trade Agreements on Foreign Direct Investment in the Asia-Pasific Region, in Findlay, C. (ed.), ASEAN+1 FTAs and Global Value Chains in East Asia, ERIA Research Project Report 2010-29 (2011).

${ }^{10}$ See Vergano R. Paolo and Tobias Dolle, Free Trade Agreements and Regulatory Change: Examples from the Generic and Biosimilar Sectors, 51 Journal of World Trade 205, 208 (2017).

${ }^{11}$ International economists such as Jagdish Bhagwati and Anne O. Krueger strongly advocate that the U.S. and other national governments should not pursue FTAs at the expense of multilateral negotiations in the WTO. FTAs are by definition discriminatory and therefore trade diverting. See William H. Cooper, Free Trade Agreements: Impact on U.S. Trade and Implications for U.S. Trade Policy Specialist in International Trade and Finance 11 (2014).
} 
adjudicated with appropriate remedies is the cornerstone of encouraging FTA utilization. ${ }^{12}$ To provide the inducement, FTAs provide that failure to comply with FTA obligations may trigger the dispute resolution mechanism and result in retaliatory measures or a claim for damages or the imposition of a fine or other negative consequence. ${ }^{13}$ Even if no disputes are expected, dispute settlement provisions in a FTA reinforce commitments of parties and assure investors that the FTA provides a solid ground for investment.

The dispute settlement mechanism in FTAs is necessary as they provide means to settle disagreements on interpretation or compliance with treaty obligations. The dispute settlement mechanism help ease tensions among FTA parties and maintain healthy relationships among trading partners. ${ }^{14}$ To put is differently, dispute settlement provisions in FTAs provide an organized way for its members to settle disputes otherwise lingering disputes can harm bilateral relations and reduce the FTAs' benefits.

In addition to preventing spillovers of disputes, dispute resolution mechanism is considered crucial tool to provide an authoritative interpretation of the rules and norms of a treaty. ${ }^{15}$ This can enhance commitments of the parties and legitimacy of the FTA itself. Ultimately, the existence of dispute resolution mechanism in FTAs is fundamental to the process of economic integration as it facilitates a deeper and wider integration by

\footnotetext{
${ }^{12}$ The way in which an international treaty ensures that its signatories actually comply with their treaty obligations is one of the critical factors determining the effectiveness and efficiency of the treaty. See Abram Chayes and Antonia Handler Chayes, The New Sovereignty; Compliance with International Regulatory Agreements 3-4 (1995).

${ }^{13}$ See for example NAFTA chs. 11, 20, Can.-Mex.-U.S., Dec. 17, 1992, 32 I.L.M. 289 and 605 (1993); Korea FTA chs. 11, 22.

${ }^{14}$ Dispute resolution mechanism can reduce the number of economic and political disputes that could lead to military conflict. See E.D. Mansfield and B.M. Pollins (eds.), Economic Interdependence and International Conflict: New Perspectives on an Enduring Debate 222-224 (2003). See also Yuval Shany, The Competing Jurisdictions of International Courts and Tribunals 3-5 (2003).

${ }^{15}$ See Abram Chayes and Antonia Handler Chayes, supra note 27, at 24.
} 
providing an institutional framework of jurisprudence to develop and increase access to justice by members of the FTA. ${ }^{16}$

The existence of dispute resolution mechanism shifts the balance in FTAs from power-oriented to rule-oriented legal systems. ${ }^{17}$ In recent years, a large amount of criticism has been leveled against dispute settlement mechanisms in FTAs. For example, FTAs in general, and their dispute resolution provisions in particular, are seen as a means by which developed countries to export their laws into the other countries that are party to the FTAs. ${ }^{18}$ Furthermore, dispute settlement provisions are considered as overriding domestic court systems and sovereignty. ${ }^{19}$ Despite the criticism leveled against dispute resolution mechanisms, their presence in FTAs is of paramount importance in providing stability and incentive for parties to engage in trade. If dispute settlement mechanism fails at encouraging trade, FTAs will not be as successful as the potential. Thus, the dispute settlement mechanism is an important or perhaps even overriding focus in the establishment of FTAs.

\section{Dispute Settlement Mechanism under EU Association Agreements with Arab Countries}

The Euro-Mediterranean Partnership started in 1995 with the Barcelona Process. The Barcelona Declaration established a framework of political, economic and social relations

\footnotetext{
${ }^{16}$ See David Simmons, Caribbean Court of Justice: A Unique Institution of Caribbean Creativity, 29 Nova L. Rev. 171, 177-178 (2005).

${ }^{17}$ See John H. Jackson, The World Trading System, 110-11 (2ed., 1997).

${ }^{18}$ See Mark B. Baker, No Country Left Behind; Exporting of U.S. Legal Norms Under the Guise of Economic Integration, 19 Emory Int'l L. Rev. 1321, 1324 (2005).

${ }^{19}$ See Josh Wingrove and Eric Martin, Canada, Mexico may Keep Nafta Investor Dispute System without U.S, available a $\mathrm{t}<\mathrm{https}$ //www.bloomberg.com/news/articles/2018-01-25/canada-mexico-may-keep-naftadispute-resolution-without-u-s $>$ (January 25, 2018).
} 
between the EU and some Southern Mediterranean Partners. ${ }^{20}$ These Partners were

Algeria, Cyprus, Egypt, Israel, Jordan, Lebanon, Malta, Morocco, the Palestine

Authority, Syria, Tunisia and Turkey.

The Barcelona Declaration has as one of its main objectives, the establishment of the

Euro Mediterranean Free Trade Area by $2010 .^{21}$ The means of achieving the free trade

area is through Association Agreements concluded between the EU and the

Mediterranean countries. Currently, there are association agreements with Tunisia, Israel,

Morocco, Jordan, and Egypt. ${ }^{22}$

The dispute settlement process in the EU association agreements with Tunisia,

Israel, Morocco, Jordan, and Egypt is short and similar in drafting. Only one article in

each of these association agreements address dispute settlement.

The EU Association Agreements with Arab countries provides the basis of the

dispute settlement mechanism. ${ }^{23}$ The panel mandate is limited. One party can bring an

\footnotetext{
${ }^{20}$ See Amichai Magen, The Shadow of Enlargement: Can the European Neighborhood Policy Achieve Compliance? 12 Colum.J. Eur. L. 383, 392 (2006).

${ }^{21}$ See Ferdi De Ville and Vicky Reynaert, The Euro-Mediterranean Free Trade Area: an Evaluation on the Eve of the (Missed) Deadline 356 L'Europe en Formation (2010).

22 See Euro-Mediterranean Agreement establishing an association between the European Communities and their Member States of the one part, and the Republic of Tunisia, of the other part, 1998, (OJ L 97/2) signed on 17.07.95, entry into force 1.03.98. 87. See also Euro-Mediterranean Agreement establishing an association between the European Communities and their Member States of the one part, and the State of Israel, of the other part, 2000, (OJ L 147/3) signed on 20.11.95, entry into force 01.06.00. 88. See also Euro-Mediterranean Agreement establishing an association between the European Communities and their Member States of the one part, and the Kingdom of Morocco, of the other part, 2000, (OJ L 70/2) signed on 26.02.96, entry into force 01.03.00. See also Euro-Mediterranean Agreement establishing an association between the European Communities and their Member States of the one part, and the Kingdom of Jordan, of the other part, 2002, (OJ L 129/3) signed on 24.11.97, entry into force 15.05.02. See also Agreement in the form of an exchange of letters concerning the provisional application of the trade and trade-related provisions of the Euro-Mediterranean Agreement establishing an association between the European Communities and their Member States of the one part, and the Arab Republic of Egypt, of the other part, 2003, (OJ L 345/115) signed on 25.06.01, entry into force 01.01.04. See also Euro-Mediterranean Agreement establishing an association between the European Communities and their Member States of the one part, and People's Democratic Republic of Algeria, of the other part, 2002, (OJ L 265/1) signed on 10.10 .05 , entry into force 1.09 .05 .

${ }^{23}$ See Association between the European Communities and the Republic of Tunisia, supra note 95, art. 86, Association between the European Communities and Israel, art.75, Association between the European
} 
action against the other if a dispute arises concerning the interpretation or the application of the association agreement. ${ }^{24}$ There is no provision concerning non-violation claims.

The Association Council is tasked, among other things, with settling disputes by a decision. The Association Council consists of representatives from EC Council, EC Commission, and representatives from Arab government in question. ${ }^{25}$ The Association Council plays a conciliatory role in the dispute settlement process and can settle the matter by a decision. However, several matters regarding the decision of the Association Council are not clear. For example, the way in which the decision is taken is ambiguous. Moreover, any party to the Association Agreement can block the adoption of the decision.

In case the matter could not be settled by the Association Council's decision, then the matter is referred to arbitration. ${ }^{26}$ The arbitration panel consists of three arbitrators. Each party nominates one arbitrator and the Association Council appoints the third arbitration. ${ }^{27}$ The EU Association Agreements with Arab countries do not prescribe time

Communities and Morocco art. 86, Association between the European Communities and Jordan, art. 97, Association between the European Communities and Egypt, art. 82, and Association between the European Communities and Algeria, art. 100.

${ }^{24} I d$.

${ }^{25}$ See Association between the European Communities and the Republic of Tunisia, supra note 95, art. 79, Association between the European Communities and Israel, art.68, Association between the European Communities and Morocco art. 79, Association between the European Communities and Jordan, art. 90, Association between the European Communities and Egypt, art. 75, and Association between the European Communities and Algeria, art. 93.

${ }^{26}$ See Association between the European Communities and the Republic of Tunisia, supra note 95, art. 86, Association between the European Communities and Israel, art.75, Association between the European Communities and Morocco art. 86, Association between the European Communities and Jordan, art. 97, Association between the European Communities and Egypt, art. 82, and Association between the European Communities and Algeria, art. 100.

${ }^{27}$ See Association between the European Communities and the Republic of Tunisia, supra note 95, art. 86.4, Association between the European Communities and Israel, art.75.4, Association between the European Communities and Morocco art. 86.4, Association between the European Communities and Jordan, art. 97.4, Association between the European Communities and Egypt, art. 82.4, and Association between the European Communities and Algeria, art. 100.4. 
limits for appointing the arbitrators. ${ }^{28}$ This is an issue which could prolong the dispute settlement process. It is unclear if the EU Association Agreements with Arab countries maintain a roster of arbitrators from which parties can select the arbitrators. Furthermore, there are no provisions that govern nationality and qualification of arbitrators. Additionally, the EU Association Agreements with Arab countries do not provide for working procedures for the arbitration panel i.e. procures, code of conduct, and interim review.

The decision the arbitration panel may not be binding. There are no clear provisions in the EU Association Agreements with Arab countries that shed light on the binding nature of the panel decision. ${ }^{29}$ However, it is assumed that parties to the dispute may feel obliged to comply with panel decision fearing being labeled as violators of the Association Agreement. In addition, non-compliance with the panel decision could put the whole Association Agreement in jeopardy.

The EU Association Agreements with Arab countries include provisions regarding compliance procedures. Each party is required to take the steps required to implement the decision of the arbitrators. ${ }^{30}$ However, the EU Association Agreements do no set time limits for compliance with panel decisions. Therefore, compliance can vary from one dispute to another. Moreover, it is unclear what steps need to be taken in order to comply with the panel decision. For instance, the EU Association Agreements do not require prompt compliance or reasonable period of time to take the necessary steps. The nature of the steps that need to be taken is unclear. Is withdrawal of the violating measure suffice

\footnotetext{
${ }^{28}$ The complainant selects one arbitrator and the respondent party nominates another arbitrator within the following two months. Id.

${ }^{29} \mathrm{Id}$.

${ }^{30} I d$.
} 
or compensation is enough? It seems that the compliance provisions of the EU

Associations Agreements with Arab countries raise more than questions than providing clear guidelines for settling disputes.

The EU Associations Agreements with Arab countries do not provide for retaliation in case of non-compliance with the arbitrators' decision. Retaliation is allowed only when a party considers that the other party has failed to fulfil an obligation under the Association Agreement. ${ }^{31}$ In that scenario, the party is allowed to take the "appropriate measures" even without consultation with the other party. The complainant party is required to supply the Association Council with all relevant information with a view to seeking a solution acceptable to all parties. ${ }^{32}$ In sum, the EU Association Agreements with Arab countries do not provide pathway for enforcing panel decision. Generally, compliance could occur only if the complainant party can enforce compliance through the threat of retaliation.

\section{Assessment of Dispute Settlement Mechanism under EU Association Agreements with Arab Countries}

The procedures of dispute settlement under the EU Association Agreements with Arab countries, to some extent, do not offer potent means for resolving disputes. The EU Association Agreements with Arab countries are akin, more or less, to the early years of the GATT 1994 where diplomacy ruled over legality. ${ }^{33}$ The dispute settlement

\footnotetext{
${ }^{31}$ See Association between the European Communities and the Republic of Tunisia, supra note 95, art. 84.2, Association between the European Communities and Israel, art.79.2, Association between the European Communities and Morocco art. 92.2, Association between the European Communities and Jordan, art. 101.2, Association between the European Communities and Egypt, art. 86.2, and Association between the European Communities and Algeria, art. 100.2.

${ }^{32} I d$.

${ }^{33}$ There was a view that dispute settlement under the GATT should be a natural consequence of the negotiation process. Some countries highlighted the ambiguity of GATT rules, the political sensitivity of trade disputes, and the complex trade-offs of competing interests that go into the formulation of any trade
} 
mechanism in EU Association Agreements with Arab countries should have been strengthened since they suppose to serve as a model for the proposed Euro Mediterranean Free Trade Area.

It is difficult to evaluate the effectiveness of the dispute settlement mechanism under the EU Association Agreements with Arab countries, since data is absent to show how many disputes were settled through consultations, brought before arbitration panels, or withdrawn. ${ }^{34}$ This hints that the dispute system of these association agreements is non-or under-utilized. Therefore, development of jurisprudence under the EU Association with Arab countries is lacking and there are no precedents to which the parties in the future will observe. Difficulties in the interpretation and application of the Association Agreements would ultimately arise. However, despite the fact that the dispute settlement provisions under the EU Association Agreements with Arab countries represent to some degree an interesting language, it is doubtful that they will be used.

Frequency of trade disputes between the EU and Arab countries are associated with economic size and trade share. ${ }^{35}$ Another reason that may explain the non-existence of dispute settlement panels under the EU Association Agreements is the fact that the WTO dispute settlement procedure mostly covers disputes regarding trade.

rule. Thus, they argued that GATT dispute resolution should not be formal, legal, or adjudicatory. See David K. Tarullo, Logic, Myth and International Economic Order, 26 HARV. INT'L L. J. 533 (1985). Other countries, such as the U.S., viewed the dispute system under the GATT as rule-based system in which violations are exposed and subject to sanctions. In the U.S. view, GATT rules will become clearer and predictable if GATT dispute resolution is characterized by rule-based decisions rendered through an adjudicatory dispute resolution process, will increase compliance with GATT standards, and will alleviate protectionist pressures. See JOHN H. JACKSON ET AL., LEGAL PROBLEMS OF INTERNATIONAL ECONOMIC RELATION 339 (1995).

${ }^{34}$ WTO panel reports are always published. See WTO, Dispute Settlement- Disputes by Members < https://www.wto.org/english/tratop_e/dispu_e/dispu_by_country_e.htm $>$ (last visited Jan. 10, 2019).

${ }^{35}$ See Bashar H. Malkawi, Arab Countries' (Under) Participation in the WTO Dispute Settlement Mechanism, 14 Flinders Law Journal 1, 7-8 (2012). Jordan, Morocco, Egypt, and Tunisia do not make the list of top trading partners with the EU. See EU Top Trading Partners, Trade Statistics 2018, available at < http://trade.ec.europa.eu/doclib/docs/2006/september/tradoc_122530.pdf > (last visited May 13, 2019). 
The Association Counsel cannot force the offending country to remove the measure or pass an order to stop the measure from running. If an arbitration panel finds that the $\mathrm{EU}$ is in violation of its obligations under the EU Association Agreements with Arab countries and the EU does not comply, Arab countries may not be to retaliate by imposing trade sanctions against the EU. To reduce the problem of enforcement, the EU Association Agreements with Arab countries should be revised by introducing alternatives such as financial damages.

\section{Conclusions}

A strong dispute resolution mechanism is a core component of FTAs which must provide a reliable and stable venue to address meritorious claims and deliver enforceable results and demonstrates the commitments of each government to comply with the contractual obligations. Without this commitment, businesses will be reluctant to risk capital.

The EU concluded free trade agreements with Arab countries for diverse reasons within the economic and geopolitical contexts. The current dispute settlement mechanism in the EU Association Agreements with Arab countries and US-Arab countries FTAs has rarely if ever been invoked and should be modified to reflect legal developments as well as the possible use as a template for a comprehensive trade agreement with the Middle East. In making these suggested improvements, we take into account the marked disparity in both hard and soft power as well as economic resources between the parties to encourage FTA utilization and participation and promote the gains to a developing country such as Jordan, Algeria, Tunisia, and Egypt. 
The EU trade agreements with Arab countries share some commonalities. For example, the EU Association Agreements with Arab countries address disputes between the parties arising from the application or interpretation of the agreements or compliance with treaty obligations. In addition, these FTAs and Association Agreements establish Joint Committees and Association Councils to discuss issues of reciprocal interests, one of which is to resolve disagreements between the parties. Nevertheless, the specific terms and conditions of the dispute resolution provisions vary especially in the EU Association Agreements with Arab countries.

The EU kept its policy of not incorporating adjudicative elements in its Association Agreements with Arab countries. The EU adopted, and continues to adopt, this policy despite being the second biggest player and many years of experience under the WTO.

The dispute settlement mechanism in the EU Association Agreements with Arab countries can be improved in several concrete ways. These improvements will address potential concerns and should contribute to a higher utilization of trade agreements as well as serve as a template for a more expansive EU regional trade. While trade between the U.S. and EU on the one hand and Arab countries on the other hand remains modest, economies develop and disputes under trade agreements with Arab countries may become more likely in the future. 